\title{
ESTIMATING URBAN LEAF AREA USING FIELD MEASUREMENTS AND SATELLITE REMOTE SENSING DATA
}

\author{
By Ryan R. Jensen ${ }^{1}$ and Perry J. Hardin ${ }^{2}$
}

\begin{abstract}
Accurate estimation of urban leaf area is important in understanding the urban forest's role in heat island mitigation, pollution removal, and carbon sequestration. Remotely sensed satellite data provide an alternative method to inexpensively and nondestructively estimate this important urban biophysical variable. Ceptometer measurements of leaf area index (LAI) at 143 urban sites in Terre Haute, Indiana, U.S., were modeled as a function of reflected radiance flux sensed by the Advanced Spaceborne Thermal Emission and Reflection Radiometer (ASTER). Multiple regression models of LAI were compared to estimates produced by feed-forward back-propagation artificial neural networks. The most accurate estimation was produced by the neural network utilizing the ASTER green band and the ratio of the ASTER red and near-infrared bands. In this case, the simple correlation between the observed and predicted LAI values was moderately high $(R=0.71)$. The standard error of the LAI estimate was 1.35 . In every case, the predictive accuracy of the neural network models exceeded the multiple regression models. Examination of the parameters in the successful models indicates that the estimation of urban LAI in Terre Haute is physically predicated on the relative proportions of leaf chlorophyll, leaf spongy mesophyll, and indurate matter (e.g., concrete, asphalt, soil) constituting the individual picture elements of the satellite image.
\end{abstract}

Key Words. Leaf area; remote sensing; ceptometer; leaf area index.

The social value of the urban forest to local urban populations has long been recognized. In contrast, the impact of the urban forest on global and local environments is not clearly understood, and the impact of urban trees on carbon sequestration, mitigation of urban heat, and removal of pollution remain topics of contemporary scientific study. Land cover conversion in urban areas is typically faster than in wildland areas, thus there is a need for rapid measurement methods of urban biophysical variables that are repeatable and economically efficient.

Leaf area index (LAI) has been identified as one of the core biophysical variables for landscape monitoring at all scales (Pierce and Running 1988; Lymburner et al. 2000). LAI has three definitions in the literature but is usually standardized to represent the green area $\left(\mathrm{m}^{2}\right)$ of flat horizontal leaves per unit of ground area $\left(\mathrm{m}^{2}\right)$ (Chen and
Black 1992; Chen et al. 1997; Barclay 1998). Many scenarios of season and landscape allow LAI measurement by earth resource satellites, and LAI is a derivative data product of many remote sensing initiatives. However, few studies have examined methods of combining satellite LAI estimates with those made using ceptometers in the urban forest to estimate LAI over large urban areas.

This research extends the work of Peper and McPherson (2003) that compared the accuracy of various nondestructive field measurement devices to accurately measure urban tree LAI. In the context of that previous work, algorithmically manipulated satellite data used in this study become an additional nondestructive method of measuring urban LAI.

The objective of this research is to develop transfer equations that can be used to convert satellite LAI measurements to their gap-fraction equivalents. Our hypothesis proposes that satellite and ground LAI measurements are related and that statistical and neural network approaches can be used to interconvert between the two methods of measurement.

\section{URBAN REMOTE SENSING}

Instruments aboard remote sensing satellites measure the electromagnetic energy emitted or reflected from Earth or its atmosphere, allowing terrestrial objects to be distinguished and characterized. For example, when illuminated by the noonday sun, grass on an irrigated golf course is not only visibly green but also reflects intercepted infrared solar energy in proportion to the amount of its spongy mesophyll. Grass receiving insufficient moisture to maintain mesophyll turgidity may appear equally as green as adjacent wellwatered grass but would decrease significantly in infrared reflectance. If spatially extensive, this stress would be detectable from spaceborne instrumentation and would allow researchers to accurately map the affected area. Using similar logic, land cover types are mapped, and vegetation biophysical variables are measured from spaceborne instruments.

Historically, remote sensing in urban areas has been constrained by the spatial complexity of urban scenes. The problem is related to the spatial resolution of the satellite 
sensor. A single image resolution element (pixel) may be measuring the spectral response of a land cover mixture rather than a single land cover type. For example, a suburban pixel may represent a mixture of grass, asphalt, concrete, and roof shingles. This kind of spectral mixing makes urban remote sensing less amenable to statistical methods that assume normal distributions and no measurement error. Newer spaceborne instruments, having finer spatial resolutions, reduce the constraint and provide better data for urban remote sensing (Jensen et al. 2003). The improvement in resolution is fortunate, because governments (e.g., state, county, city) and private companies annually invest hundreds of millions of dollars acquiring remotely sensed data that detail the urban landscape more effectively than through traditional "windshield surveys" (Jensen 2000).

\section{DATA AND METHODS Study Area}

The city of Terre Haute is located in Vigo County along the banks of the Wabash River in west central Indiana, U.S. (39 $\left.25^{\prime} \mathrm{N}, 87^{\circ} 25^{\prime} \mathrm{W}\right)$. Terre Haute government officials have made a conscious effort to maintain the urban tree canopy through a comprehensive tree ordinance that governs both tree removal and planting. The ordinance is administered by a tree advisory board consisting of city residents appointed by the city officials to make suggestions and recommendations to the mayor, city forester, city engineer, and city council.

\section{LAI Field Measurements}

Traditional field measurement of LAI has taken two approaches. The first approach requires the destructive harvesting of leaves within a vertical column passing upward through the entire tree canopy. The second involves collection of leaf litterfall. These direct methods are similar: They are time intensive and require many replicates to account for spatial variability in the canopy (Green et al. 1997). However, these direct LAI measurements are accurate for a very specific geographic location, are relatively easy to perform by untrained personnel, and are well understood by ecologists.

Gap-fraction analysis is a nondestructive field method that has been developed to estimate LAI. Gap-fraction analysis is predicated on the theory that the decrease in light intensity (light attenuation) with increasing depth in vegetative canopies can be described by the relationship:

$$
I L / I O=e^{-k L A I(L)},
$$

where IL/IO is the fraction of incident light at the top of the canopy $(I O)$ reaching depth $L$ in the canopy, $\operatorname{LAI}(L)$ is the cumulative LAI from the top of the canopy to point $L, k$ is a stand or species specific constant, and $e$ is the natural logarithm base (Larcher 1975; Aber and Melillo 1991). Different types of vegetation have different $k$ values, causing different rates of light attenuation for the same leaf area. The principal factor causing this is "twig angles and the angles that the foliage subtends with the twig" (Barclay 1998; see also Larcher 1975). Field-measured LAI using gap-fraction analysis assumes that leaf area can be calculated from the fraction of direct solar energy that penetrates the canopy (canopy transmittance). Gap-fraction techniques have been used to study LAI in many different forest settings (Pierce and Running 1988; Chason et al. 1991; Ellsworth and Reich 1993; Nel and Wessman 1993; Green et al. 1997).

In this study, LAI was measured using the gap-fraction approach in 143 random locations (sampling sites) throughout the study area during July and August 2001. Like most urban areas, land cover in Terre Haute consists of a wide variety of vegetated and nonvegetated patches. Vegetated areas sampled included trees, shrubs, grasses, and agricultural fields growing different varieties of corn and soybeans. Unvegetated areas included buildings, streets, parking lots, ponds, lakes, and the Wabash River. The randomly selected sampling sites represented all major land cover types in Terre Haute.

Each of the 143 sampling sites was defined as a $20 \times 20$ $\mathrm{m}(65.6 \times 65.6 \mathrm{ft})$ quadrat identified by the global positioning system coordinates of its center. At each sampling point, 16 below-canopy, photosynthetically active radiation (PAR) measurements were collected, one in each cardinal direction at each corner of the $20 \mathrm{~m}$ quadrat. The PAR measurements were collected using a Decagon AccuPar Ceptometer ${ }^{\mathrm{TM}}$ held approximately $1 \mathrm{~m}(3.3 \mathrm{ft})$ above the ground beneath the tree cover. The AccuPar Ceptometer consists of a linear array of 80 adjacent, $1 \mathrm{~cm}^{2}\left(0.16 \mathrm{in}^{2}\right)$ PAR sensors mounted rigidly along a bar and oriented so that when the operator holds the ceptometer horizontally, the PAR passing downward through the canopy can be measured. The ceptometer stored the 16 PAR samples taken at each sampling site and calculated the LAI average automatically. This sitewide LAI average was then recorded along with general operator notes regarding the sampling site character.

\section{Satellite Sensor Data}

Data from the Advanced Spaceborne Thermal Emission and Reflection Radiometer (ASTER) sensor were used for comparison to the field LAI measurements. ASTER data are collected in several wavelengths, often referred to as bands. This study employed ASTER bands 1, 2, and 3 measuring the green, red, and near-infrared segments of the electromagnetic spectrum $(520-600 \mathrm{~nm}, 630-690 \mathrm{~nm}$, and 790-860 $\mathrm{nm})$, respectively. These wavelengths are used in vegetation studies because of their correlation to the quantity and 
health of green vegetation (Jensen 2000). Remote sensing data are commonly used to calculate vegetation indicesdimensionless, radiometric measures of the relative abundance of green vegetation, including LAI (Jensen 2000). One of the most common vegetation indices is the Normalized Difference Vegetation Index (NDVI). The NDVI is calculated using the equation (Rouse et al. 1974):

$$
N D V I=\frac{N I R-R E D}{N I R+R E D}
$$

where NIR is the near-infrared reflected radiant flux, and $R E D$ is the red reflected radiant flux.

An ASTER image of the study area acquired in July 2001 was used for this investigation. The image had a spatial resolution of $15 \mathrm{~m}$ (49.5 ft). Using a United States Geological Survey digital raster graphic image, the ASTER scene was geometrically adjusted to the same coordinate system used for the field data collection. This adjustment ensured that the 143 sample sites could be accurately registered to the ASTER data.

\section{Estimating LAI Using Regression}

As mentioned above, the principal objective of this research was to create transfer equations that could be used to convert satellite LAI measurements to their gap-fraction equivalents. Because correlation and regression are common methods used to model forest biophysical characteristics with remotely sensed data (e.g., Jensen et al. 2000), their use was suggested. In this instance, multiple regression analysis was performed using brightness values from the three ASTER bands as the independent variables (Table 1). Because previous remote sensing research has shown that ratios and vegetation indexes derived from brightness values (e.g., NDVI) frequently measure vegetation differences better than the direct brightness values alone (Fassnacht et al. 1997; Jensen 2000), five derived independent variables were also explored in the regression process. These variable are described in Table 1. In all regressions, the average field site LAI value $\left(L A I_{o b s}\right)$ was the dependent variable.

Table 1. Variables used in both the regression and neural network exploration.

\begin{tabular}{ll}
\hline Variable & Meaning \\
\hline GREEN & ASTER 520-600 nm band (green band) \\
RED & ASTER 630-690 nm band (red band) \\
IR & ASTER 790-860 nm band (infrared band) \\
GRRD_RAT & Green/red band ratio \\
RDIR_RAT & Red/infrared ratio \\
NDVI & Normalized difference vegetation index (see Equation 2) \\
GRRD_DIF & Green-red band difference \\
RDIR_DIF & Red-infrared band difference \\
\hline
\end{tabular}

The goodness of the regression models was measured in two ways. The first is the standard error of the estimate (standard error of the estimate is synonymous for root mean square error; the former term is preferred in regression, whereas the latter term is preferred in neural network studies) defined by

$$
S E E=\sqrt{\frac{\sum_{i=1}^{n}\left(L A I_{\text {pred }}-L A I_{o b s}\right)^{2}}{n}},
$$

where $L A I_{\text {pred }}$ is the LAI for a given fieldsite predicted by the regression. The summation is iterated over all the observations in the dataset $(i=1$ to $n$ ). Smaller values of SEE indicate better fit between model and observed data and can be interpreted as the best estimate of the standard deviation of the observations around the regression line. The second method was the common multiple correlation coefficient $(R)$ as described in Marascuilo and Levin (1983). The minimum acceptable level of significance in all the statistical analyses was 0.05 .

\section{Estimating LAI Using a Back-Propagation Feed- Forward Network}

Artificial neural networks (ANNs) grew out of research in artificial intelligence, specifically attempts to mimic the fault tolerance and learning capacity of biological neural systems by modeling the low-level structure of the brain. Research on ANNs has been motivated from their inception by the recognition that the brain computes in a very different way than digital computers (Haykin 1994).

A neuron is the fundamental processing unit of an ANN. Artificial neurons are analogous to biological neurons in the human brain. ANN behavior resembles that of the brain in two respects. First, knowledge is acquired by the network through a learning process. Secondly, interneuron connection strengths known as synaptic weights are used to store knowledge (Haykin 1994). ANNs do not rely on statistical relationships for function fitting but adaptively estimate continuous functions from data without mathematically describing how outputs depend on inputs (e.g., adaptive model-free function estimation using a nonalgorithmic strategy) (Gopal and Woodcock 1996).

ANNs have been used in remote sensing applications to classify images (Bischof et al. 1992; Hardin 2000) and incorporate multisource data (Benediktsson et al. 1990). ANN classifiers have been successfully used with remote sensing data because they take advantage of the ability to incorporate non-normally distributed numerical and categorical GIS data and image spatial information (Jensen et al. 2000).

Several forest studies have demonstrated the utility of coupling ANN approaches with satellite data. For example, 
Jensen et al. (2000) used an ANN to discriminate conifer stand age in southern Brazil using remotely sensed imagery. That study demonstrated that ANNs were (1) competent to model the complex nonlinearity of biophysical forest processes, (2) better at estimating conifer stand age than traditional image processing techniques, (3) ideal for modeling the latent complexity of plant biophysical characteristics during the plant life cycle, and (4) able to explain more variance in forest biophysical parameters than their traditional statistical counterparts. In another study, Jensen and Binford (2004) found that ANNs were more accurate than traditional statistical techniques to estimate LAI in forested ecosystems throughout north central Florida.

For this research, a back-propagation feed-forward ANN was created and trained using the variables shown in Table 1 as inputs, and the fieldsite LAI (i.e., $L A I_{o b s}$ ) as the output. This procedure is directly analogous to the multiple regression approach described previously in this article, in which ASTER variables and $L A I_{o b s}$ were the independent and dependent variables, respectively.

The procedure used to build the ANN models generally followed Hardin (2000). The calibration of several candidate networks required trial and error. The networks were trained with different variable combinations, different numbers of hidden neurons, different learning rates, and different momentum rates until an acceptable error rate was obtained or further improvement was unlikely. Parsimony was also sought in the neural network solutions. Given equal predictive value from alternative network configurations, the network with the fewest hidden neurons was considered superior to more complex networks.

Like the regression approach described above, the SEE was also used to measure the accuracy of the network predictions by comparing $L A I_{\text {obs }}$ values against $L A I_{\text {pred }}$ values across all 143 fieldsites. $R$ was also calculated for neural networks by regressing predicted $L A I$ values against their observed counterparts. Use of the same accuracy metrics allowed the regression results to be compared to the ANN outcome.

\section{RESULTS AND DISCUSSION}

The field LAI measurements were made at 143 Terre Haute area locations $(n=143)$. The maximum and minimum LAI recorded were 7.7 and 0.0 , respectively. The mean LAI measured was $1.2(s=1.9)$.

\section{Regression Results}

All possible single variable regression models were tested. Several provided statistically significant predictive ability. The regression model providing the highest correlation coefficient $(R=0.60)$ and lowest error $(S E E=1.54)$ was created from the ratio of the ASTER green and ASTER red bands (GRRD_RAT). In unstandardized form, the predictive model was

$$
L A I_{\text {pred }}=4.79 \times G R R D \_R A T-5.81 .
$$

The best two-variable model included the same ratio as Equation 4 but added the infrared ASTER band. The predictive equation using these two variables was

$$
L A I_{\text {pred }}=3.99 \times G R R D \_R A T+0.02 \times I R-7.10 .
$$

This model lowered the standard error of the single variable model by only 3\% (SEE $=1.51)$ and improved the simple correlation by only $5 \%(R=0.62)$. The addition of further variables did not improve the predictive ability of the model.

For all the regression equations previously cited, their coefficients, and constants were significant at the 0.05 level. Use of the single variable model (Equation 4) is suggested because of its simplicity. The direction of the coefficient signs for the regression variables is logical. As the amount of green reflectance increases and red reflectance decreases, the ratio GRRD_RD increases mathematically and $L A I_{\text {pred }}$ also increases. In addition, as infrared reflectance increases, so does $L A I_{\text {pred }}$. These results suggest that both the ratio and the infrared band are measuring the same physical phenomena; they are measuring the increase in green reflectance as leaf area increases with the co-occurring loss of ground reflectance.

\section{Artificial Neural Network Results}

All the variables in Table 1 were submitted separately to ANN analysis to create a single variable model explaining LAI. Three single-variable networks produced nearly equivalent LAI predictive accuracy $(R \approx 0.69$, SEE $\approx 1.40)$. These three models employed respectively the ASTER green band, NDVI, and the ratio between the ASTER red and infrared variables (RDIR_RAT). In all three cases, networks with two neurons in a single hidden layer were sufficient for fitting the network. The best two variable model tested included the ASTER green band (GREEN) and the ratio between the ASTER red and infrared bands (RDIR_RAT) trained on single hidden layer of three neurons. This network produced a moderately high $R$ value $(R=0.71)$ with an SEE of 1.35. A Visual Basic function that reproduces the network output is shown in Figure 1. This function returns $L_{\text {pred }}$ when passed GREEN, RED, and INFRARED brightness values. The variable RDIR_RAT is calculated inside the function from RED and INFRARED and then used with GREEN in the network calculations. No three-variable network models significantly exceeded the predictability of this two-variable network model. 


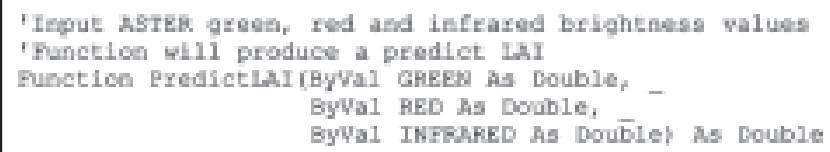

End runction

Figure 1. Visual Basic function of neural network to predict LAI from ASTER band brightness values.

Table 2. Comparison of regression and neural network models. In all cases, the neural network models were better than the regressionbased models for predicting LAI.

\begin{tabular}{lllll}
\hline Model reference & Building method & Variables & $R$ & SEE \\
\hline Equation 3 & Regression & GRRD_RAT & 0.60 & 1.54 \\
Equation 4 & Regression & GRRD_RAT, IR & 0.62 & 1.51 \\
$*$ & ANN & GREEN & 0.69 & 1.39 \\
$*$ & ANN & NDVI & 0.68 & 1.39 \\
$*$ & ANN & RDIR_RAT & 0.69 & 1.39 \\
Figure 1 & ANN & GREEN, RDIR_RAT & 0.71 & 1.35 \\
\hline
\end{tabular}

The interpretation of the neural network results follows the same logic used in discussing the regression results. $L A I_{\text {pred }}$ increases with increased reflectance in the ASTER green band. The ratio of the red to infrared reflectance (RDIR_RAT) assumes the role that GRRD_RAT played in the regression analysis; it is a measure of the ratio of background to photosynthetically active vegetation or healthy, spongy leaf mesophyll. With an increase in vegetation at the expense of impervious material, infrared reflectance in the ratio increases while red reflectance decreases. This causes a corresponding increase in $L A I_{\text {pred }}$.

\section{CONCLUSION}

As shown in Table 2, the ANN technique was superior to the multiple regression approach. In all cases, the ANN produced higher values of $R$ and lower values of SEE than did regression. These results provide another case study demonstrating that a biophysical variable critical to urban study (i.e., LAI) can be predicted from remotely sensed satellite data and be more accurately predicted using a feedforward back-propagation neural network than multiple linear regression.

Using ANNs to estimate LAI could enhance the accuracy of some studies that have relied on traditional regression techniques in the past. To improve such studies, ANNs could be created and trained using representative ecosystem in situ LAI samples and then used to estimate LAI in other image areas. For example, after measuring in situ urban LAI using one of the methods described by Peper and McPherson (2003), an ANN could be created and trained that is unique to that specific urban area. A program such as that shown in Figure 1 could then be used to estimate LAI in the unsampled remainder of the urban area. This is demonstrated in Figure 2. In this example, LAI has been estimated for the Terre Haute region using the ANN represented in Figure 1. This kind of map may be useful when urban planners and others examine the distribution of LAI in urban and suburban areas.

While the ANN method proved most accurate in Terre Haute, this may not be the case in other urban areas under different environmental conditions. Future research could focus on these issues and determine whether ANNs provide the most accurate method to estimate LAI elsewhere. Also, care should be taken to ensure that the network algorithms and regression equations developed in this research are only applied in areas having similar solar zenith angles and vegetation types. While this study was completed at the landscape level, it suggests that artificial neural networks may be created and trained in other areas throughout the world to provide an accurate method to remotely estimate LAI. Further, these models 
can be used to answer important geographic questions by describing temporal and spatial LAI dynamics at landscape to regional scales (e.g., Jensen 2002). Of equal importance, this methodology can help land managers, conservationists, and urban foresters formulate urban environmental policy that is empirically supported by inexpensive remotely sensed biophysical data.

\section{LITERATURE CITED}

Aber, J.D., and J.M. Melillo. 1991. Terrestrial Ecosystems. Saunders College Publishing, Chicago, IL.

Barclay, H.J. 1998. Conversion of total leaf area to projected leaf area in lodgepole pine and Douglas-fir. Tree Physiol. 18:185-193.

Benediktsson, J.A., P.H. Swain, and O.K. Ersoy. 1990. Neural network approaches versus statistical methods in classification of multisource remote sensing data. IEEE Trans. Geosci. Remote Sensing 28:540-551.

Bischof, H., W. Schneider, and A.J. Pinz. 1992. Multispectral classification of Landsat images using neural networks. IEEE Trans. Geosci. Remote Sensing 30:482-490.

Chason, J.W., D.D. Baldocchi, and M.A. Huston. 1991. A comparison of direct and indirect methods for estimating forest canopy leaf area. Agric. For. Meteorol. 57:107-128.

Chen, J.M., and T.A. Black. 1992. Defining leaf-area index for non-flat leaves. Plant Cell Environ. 15:421-429.

Chen, J.M., P.M. Rich, S.T. Gower, J.M. Norman, and S. Plummer. 1997. Leaf area index of boreal forests: Theory, techniques, and measurements. J. Geophys. Res. Atmos. 102:29429-29443.

Ellsworth, D.S., and P.B. Reich. 1993. Canopy structure and vertical patterns of photosynthesis and related leaf traits in a deciduous forest. Oceologia 96:169-178.

Fassnacht, K.S., S.T. Gower, M.D. MacKenzie, E.V. Nordheim, and T.M. Lillesand. 1997. Estimating the leaf area index of north central Wisconsin forests using the Landsat Thematic Mapper. Remote Sensing Environ. 61:229-245.

Green, E.P., P.J. Mumby, A.J. Edwards, C.D. Clark, and A.C. Ellis. 1997. Estimating leaf area index of mangroves from satellite data. Aquatic Bot. 58:11-19.

Gopal, S., and C.E. Woodcock. 1996. Remote sensing of forest change using artificial neural networks. IEEE Trans. Geosci. Remote Sensing. 34:398-404.

Hardin, P.J. 2000. Neural networks versus nonparametric neighbor-based classifiers for semisupervised classification of Landsat Thematic Mapper imagery. Optical Eng. 39:1898-1908.

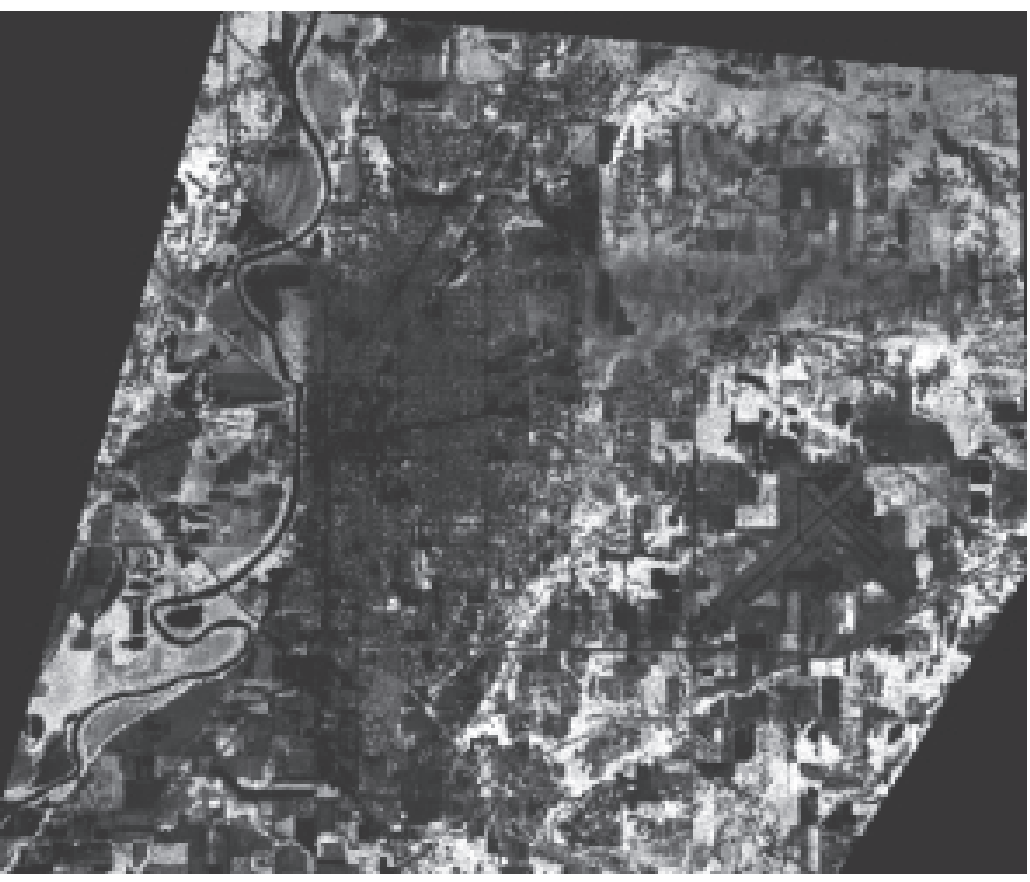

Figure 2. Estimated LAI map of the Terre Haute area computed using the artificial neural network and three ASTER bands. Lighter areas represent higher LAI values. Note the city center in the middle left of the image and Terre Haute International Airport in the middle right of the image.

Haykin, S. 1994. Neural Networks: A Comprehensive Foundation. Prentice Hall, Upper Saddle River, NJ.

Jensen, J.R. 2000. Remote Sensing of the Environment: An Earth Resources Perspective. Prentice Hall, Upper Saddle River, NJ.

Jensen, R.R. 2002. Spatial and temporal leaf area index dynamics in a north central Florida, USA preserve. Geocarto Int. 17(4):45-52.

Jensen, R.R., and M.W. Binford. 2004. Measurement and comparison of leaf area index estimators derived from satellite remote sensing techniques. Int. J. Remote Sensing 25:4251-4265.

Jensen, R.R., J.R. Boulton, and B.T. Harper. 2003. The relationship between urban leaf area and household energy usage in Terre Haute, Indiana, U.S. J. Arboric. 29(4):226-230.

Jensen, J.R., F. Qui, and M. Ji. 2000. Predictive modeling of coniferous forest age using statistical and artificial neural network approaches applied to remote sensor data. Int. J. Remote Sensing. 20:2805-2822.

Larcher, W. 1975. Physiological Plant Ecology. SpringerVerlag, New York, NY.

Lymburner, L., P.J. Beggs, and C.R. Jacobson. 2000. Estimation of canopy-average surface-specific leaf area using Landsat TM data. Photogram. Eng. Remote Sensing. 66:183-191. 
Marascuilo, L.A., and J.R. Levin. 1983. Multivariate Statistics in the Social Sciences. Brooks/Cole, Monterey, CA.

Nel, E.M., and C.A. Wessman. 1993. Canopy transmittance models for estimating forest leaf area index. Can. J. For. Resourc. 23:2579-2586.

Peper, P.J., and E.G. McPherson. 2003. Evaluation of four methods for estimating leaf area of isolated trees. Urban For. Urban Green. 2:19-29.

Pierce, L.L., and S.W. Running. 1988. Rapid estimation of coniferous forest leaf area index using a portable integrating radiometer. Ecology 69:1762-1767.

Rouse, J.W., R.H. Haas, J.A. Schell, and D.W. Deering. 1974. Monitoring vegetation systems in the Great Plains with ERTS, pp 3010-3017. In Proceedings, Third Earth Resources Technology Satellite-1 Symposium, Greenbelt. NASA SP-351.

${ }^{1 *}$ Department of Geography, Geology, and Anthropology
Indiana State University
Terre Haute, IN 47809, U.S.
r-jensen@indstate.edu

${ }^{2}$ Department of Geography

Brigham Young University

Provo, UT 84602, U.S.

*Corresponding author.

Résumé. Une estimation précise de la masse foliaire en milieu urbain est importante afin de comprendre le rôle de la forêt urbaine par rapport à l'atténuation de la chaleur, l'absorption des polluants et le captage du carbone. Les données provenant de satellites en orbite constituent une source alternative pour estimer de manière peu dispendieuse et non destructive cette variable biophysique urbaine importante. Des mesures d'index de la surface foliaire de 143 sites urbains de Terre Haute en Indiana ont été modélisées sous la forme d'une fonction du flux de réflexion de la radiation, et ce tel que détecté par l'ASTER (Advanced Spaceborne Thermal Emission and Reflection Radiometer). Des modèles de régression multiple d'index de la surface foliaire ont été comparés à des valeurs estimées qui ont été produites à partir de systèmes artificiels. L'estimation la plus précise a été produite à partir du système artificiel utilisant la bande verte de l'ASTER ainsi qu'à partir du ratio des bandes de rouge et du proche infrarouge de l'ASTER. Dans ce cas, la simple corrélation entre les valeurs observées et les valeurs prédites d'index de surface foliaire était modérément élevée $(R=0,71)$. L’erreur standard d'estimation d'index de surface foliaire était de 1,35. Dans tous les cas, le degré de précision des modèles de prédiction à partir du système artificiel excédait celui des modèles de régression multiple, L'examen des paramètres dans les modèles ayant obtenu du succès a indiqué que l'estimation de l'index de surface foliaire en milieu urbain de Terre Haute était physiquement prédictible par rapport aux proportions relatives de chlorophylle foliaire, de mésophylle foliaire spongieuse et de matières indurées (ex.: béton, asphalte, sol) qui constituaient les divers éléments des images satellite.

Zusammenfassung. Eine akkurate Schätzung der urbanen Blattfläche ist notwendig, um die Rolle der urbanen Forstwirtschaft bei der Mitigation von Hitzeinseln, der Entfernung von Umweltverschmutzung und der Kohlenstoffausfällung zu verstehen. Per Satelliten aufgenommene Daten liefern eine alternative Methode, um preiswert und ohne jegliche Zerstörung diese wichtige biophysikalische Variable zu bewerten. An 143 urbanen Standorten in Terre Haute, Indiana wurden Ceptometer-Messungen des Blattflächen-Index (LAI) als eine Funktion der reflektierten Strahlung, aufgenommen durch ASTER, modeliert. Die vielfältigen Regressionsmodelle des LAI wurden mit Schätzungen des feedforward back-propagation artificial neural networks verglichen. Die beste Schätzung wurde von dem Neutralen Netzwerk produziert bei der Verwendung des grünen ASTER-Bandes und dem Durchschnitt des roten und nahe infrarotem ASTER-Band. In diesem Fall war die einfache Korrelation zwischen beobachtetem und vorhergesagtem LAI-Wert ziemlich hoch $(R=0,71)$. Der Standartfehler bei den LAISchätzungen betrug 1,35. In jedem Fall überstieg die Akkurese der Vorhersagen der neutralen Netzwerk-Modelle die der multiplen Regressionsmodelle. Die Untersuchungen der Parameter in den erfolgreichen Modellen zeigte, dass die Schätzungen der urbanen LAI in Terre Haute physikalisch an den Proportionen des Blattchlorophylls, des Blattmesophylls und der anderen Substanzen (z.B. Beton, Asphalt, Boden) die individuellen Bildelemente des Satellitenbildes darstellen.

Resumen. La estimación precisa del área foliar urbana es importante para el entendimiento del papel del bosque urbano en la mitigación de la isla de calor, remoción de la contaminación y captura de carbono. Los datos de satélite sensados remotamente proporcionan un método alternativo para estimar de una forma no costosa y no destructiva esta importante variable biofísica urbana. Se modelaron las mediciones de índice de área foliar (LAI) con Ceptómetro en 143 sitios urbanos en Terre Haute, Indiana, como una función de la radiación reflejada sensada por el satélite radiómetro de emisión y reflexión termal (ASTER). Se compararon modelos de regresión múltiple de LAI con las estimaciones con redes neuronales producidas por las imágenes de satélite. La estimación más precisa fue producida utilizando la banda verde y la relación de rojo e infrarrojo cercano del ASTER. En este caso, la correlación simple entre los valores observados y los predichos de LAI fueron moderadamente altos $(R=0.71)$. El error estándar de LAI estimado fue 1.35. En cada caso, la precisión predictiva de los modelos de redes neuronales excedieron los modelos de regresión múltiple. El examen de los parámetros en los modelos exitosos indican que la estimación de LAI en Terre Haute es físicamente predictiva en las proporciones relativas de clorofila foliar, mesófilo esponjoso de la hoja y material inorgánico (concreto, asfalto, suelo), constituyendo los elementos pictóricos individuales de las imágenes de satélite. 